\title{
牛乳中の細菌に關する實驗的考察
}

\author{
桑原國久
}

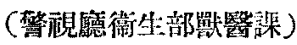

\section{AN EXPERIMENTAL CONSIDERATION ON THE BACTERIA CONTAINED IN COW-MTLK.}

K. KUWABARA.

(From the Veterinary Department, Metropolitan Police Board, Tokyo.)

I. 橉 言

目次

II. 乳房管腾より0秋行狀意

1. 熱湯 1 分間殺菌

2. 熟湯 5 分間殺菌

II. 空氮中よりの活染肰熊

3. ベ州 殺菌

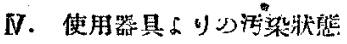

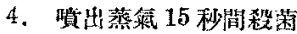

V. 擭乳夫の手の細菌數

5. 噀出蒸籍 1 分間殺菌

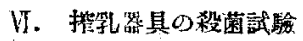

गI. 總 括

\section{I. 緒言}

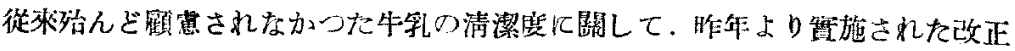

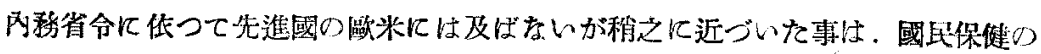

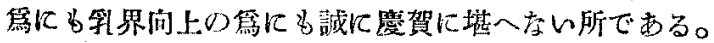

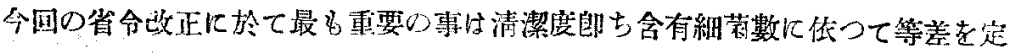

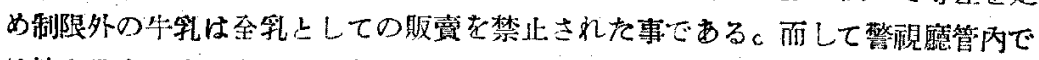

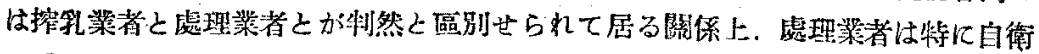

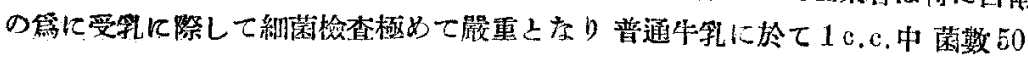




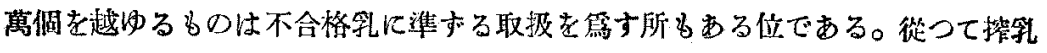

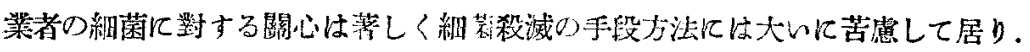

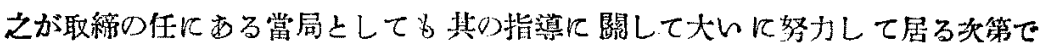
ある。

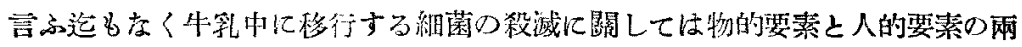

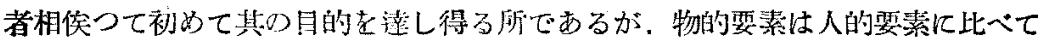

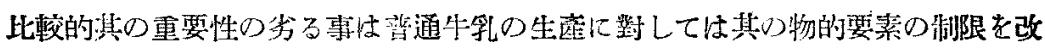
正內務省令で撤庭した事儿依つても明である。故に人的要素が優秀であつたなら 壮或る程度の細菌數つ少い牛乳を生產する事恃決して難事ではない。

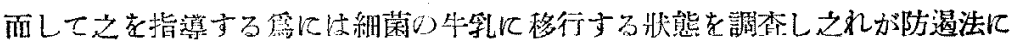

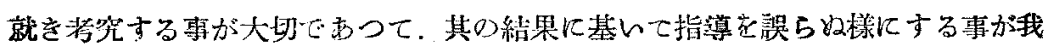
く當事者の務である。

牛乳中に細菌の移行さる緸路は第一に乳房上り，第二に大氣中より，第三に使 用器其類よりの三種に大别する事が出來るですらう，以上三種の中で最当重要で

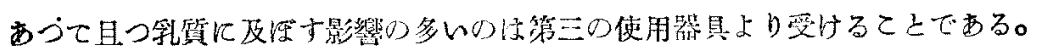
之れ郎ち省令に於て特に使用器具の殺菌を規定して要る所以で方る。

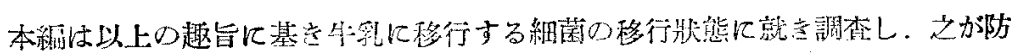

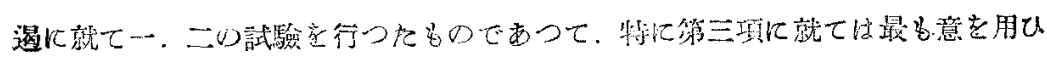

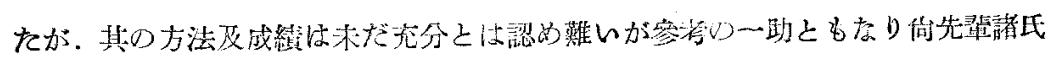

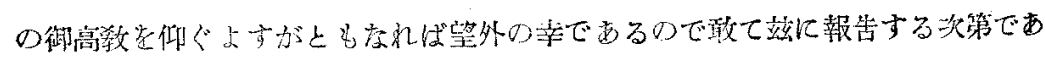
る。

\section{II. 乳房よりの移行狀篦}

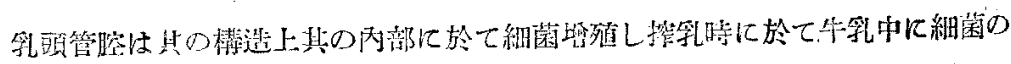
移行する事は虽然ですつて。紫に最初の一揢り二控りでは細菌數が相當多的事も

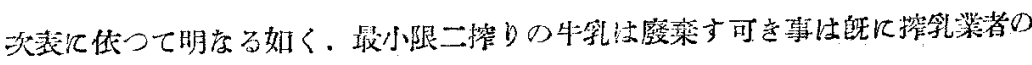

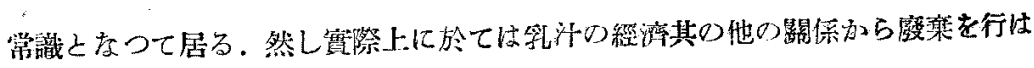




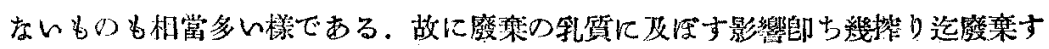
可をかに就いて先づ調查を行つた。

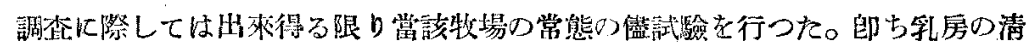

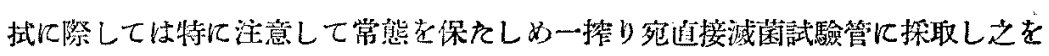

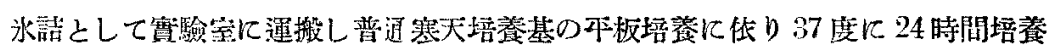

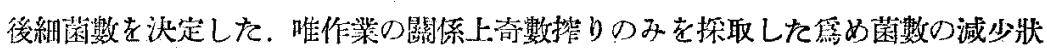

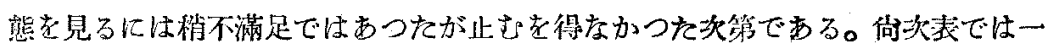

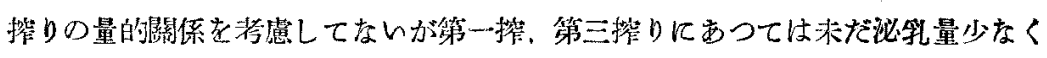

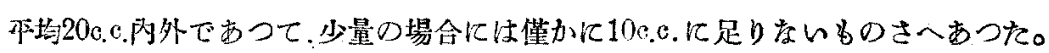

\begin{tabular}{|c|c|c|c|c|c|c|c|c|c|}
\hline & 铜查 & 綶 荡 & 數 & 1 & 数 & & 内 & 容 & \\
\hline & 例數 & $\begin{array}{l}\text { 最 高 } \\
\text { 1ce. 中 }\end{array}$ & $\begin{array}{l}\text { 最 低 } \\
\text { 1c.c.中 }\end{array}$ & $\begin{array}{l}50,000 \\
\text { 以上 }\end{array}$ & $\begin{array}{l}5 n, 000- \\
10,000 \text { 個 } 1\end{array}$ & 1,000 & $\begin{array}{l}\text { 固 } 1,000 \\
\text { i } 100 \text { 倜 }\end{array}$ & $\mid \begin{array}{l}100-1 \\
10 \text { 调 }\end{array}$ & $\begin{array}{l}\text { 10個 } \\
\text { 以下 }\end{array}$ \\
\hline 第 1 推 & 43 & 69,725 & 200 & $2^{\text {例 }}$ & $11^{\text {例 }}$ & $24^{\text {例 }}$ & $6^{6}$ 例: & $0^{0}$ & $0^{\text {例 }}$ \\
\hline 第3 挩 & $"$ & 18,000 & 50 & 0 & 2 & 17 & $2 ;$ & 1 & 0 \\
\hline 第5㩁 & $"$ & $S, 500$ & 10 & 0 & 0 & 6 & 15 & 22 & 0 \\
\hline 第 7 暀 & " & 2,575 & 5 & 0 & 0 & 3 & 8 & 29 & 3 \\
\hline 第 9 啭 & " & 1,820 & 0 & 0 & 0 & 1 & 10 & 19 & 13 \\
\hline
\end{tabular}

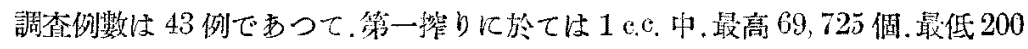

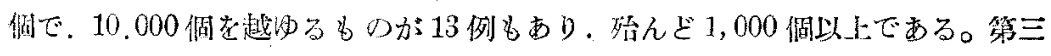

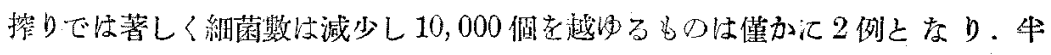

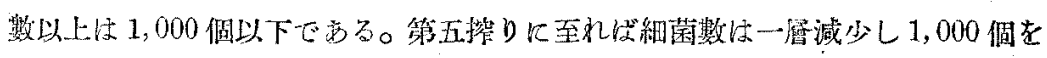

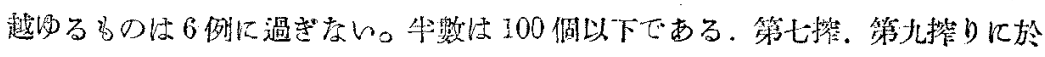

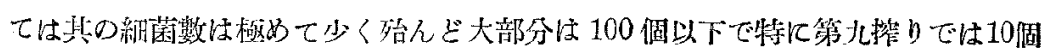
以下のものが 13 例当るる。

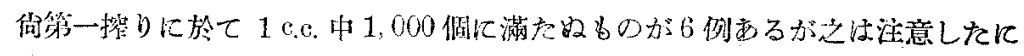

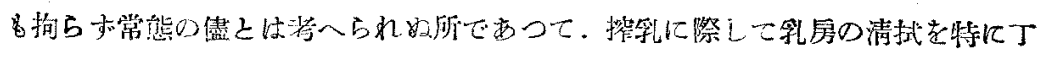

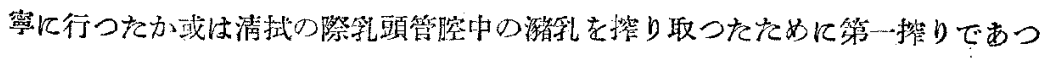

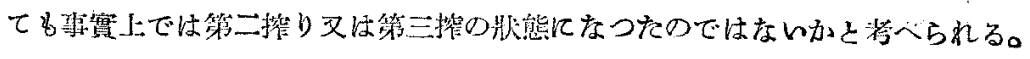

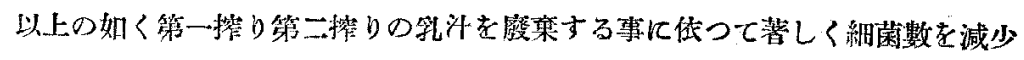




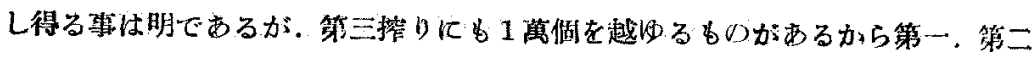

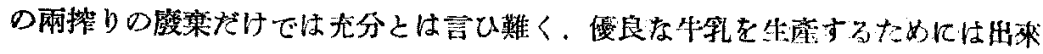
得るなら代第三控り迄發率する事が安全でする。

\section{III. 空雨中よりの污染狀態}

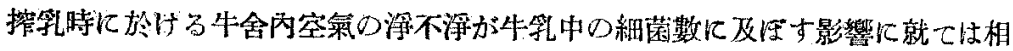
䓨喧しく言はれて居るので本調查を行つて見た。調查時儿於ける牛拿內の狀況は

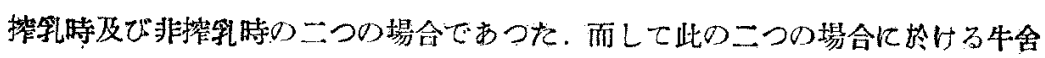

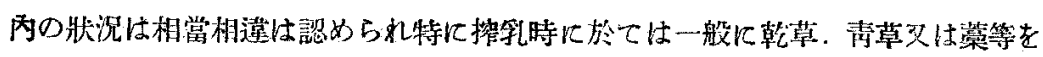

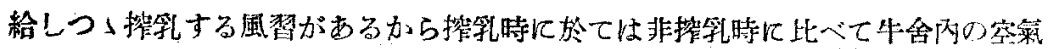
は著しく不淨の彇態にある事は明膫である。

然し本調查は同一牛含內に於て网者を比較したのでは存く茎然巽つた牛含の調 查であるから之を国别する事なく一括表示する事とした。

調查術式恃的 60 平方榞の面樍を有するシャーレ中に普通寒天培養基を流した

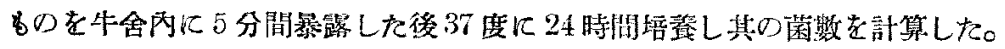

\begin{tabular}{|c|c|c|c|c|c|c|c|}
\hline & 細 菌 & & 數 & & 例 & 队 & 容 \\
\hline 調查例數 & 最 高 & 最 & 低 & $\begin{array}{l}1, \overline{0} 0 \text { 個 } \\
\text { 以 }\end{array}$ & $\begin{array}{r}1,000-\overline{0} \\
500 \text { 倜 }\end{array}$ & 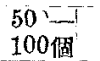 & $\begin{array}{c}100 \frown 10 \\
10 \text { 個 }\end{array}$ \\
\hline 71 & 2,980 & & 52 & 52 & 28 & 13 & 例 \\
\hline
\end{tabular}

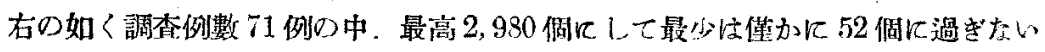
然し 1.000 個以与の\&のは比較的多々28 例即与 $40 \%$ あつた。

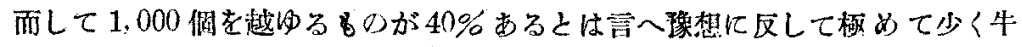

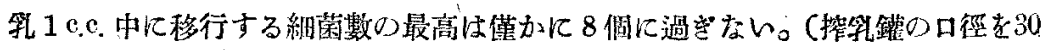

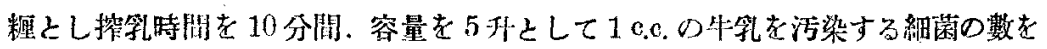

總 細 菌 數

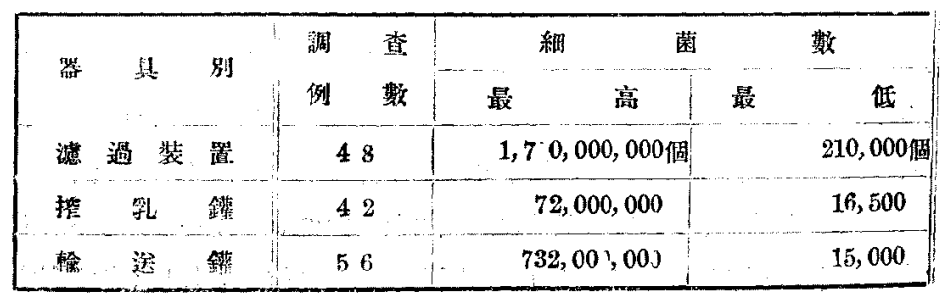




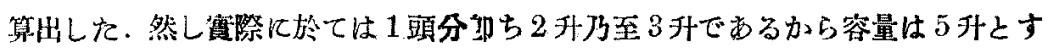
るより2-3升と見做す可をであるかる知れない).此の程度では他の器具類より

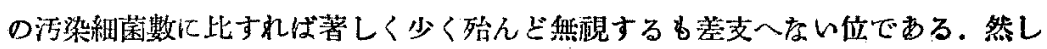

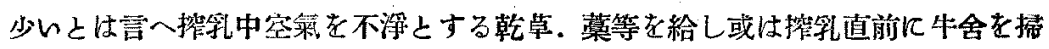
除するが如をは仙柬得る限り殷止す可をである。

\section{IV. 使用器具よりの污染状馝}

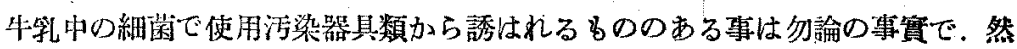
其の數が著しく多敖である事は一般に信ぜられて居る所である．歐米にては詳

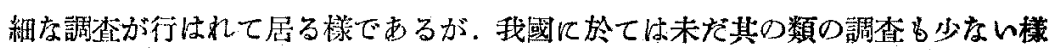
で其の一端でも知り度いと思つて調查したものである。

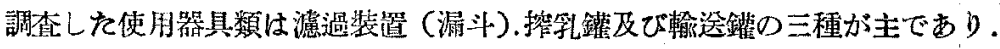

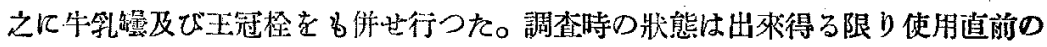

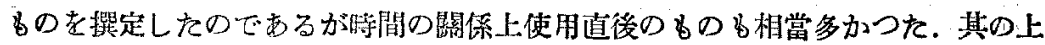
調査した牧場では各ふ獨自の洗熦法を採用して居るために條件は全く異つて居る が．表には此の區别は付けず一列に示す事にした。

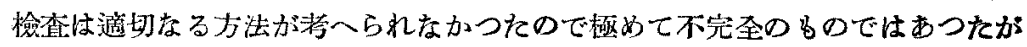

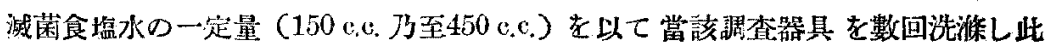

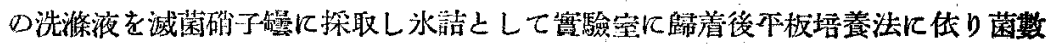
を計算した，何右の如を方法を取つたため該成績は牛乳に移行する菌数の最少限 度である䊩は司ふ迄もない事である。

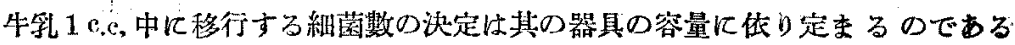

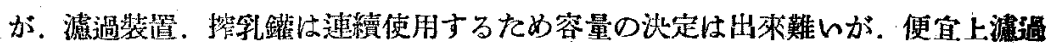

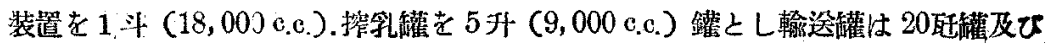
1 斗鑵の二種あつたが、を当總て 1 斗 $(18,100$ c.c.として計算した。

\begin{tabular}{|c|c|c|c|c|c|}
\hline & 例 & 數 & 队内 & 容 & \\
\hline $\begin{array}{c}1,000,000,000- \\
\text { 個 上 上 }\end{array}$ & 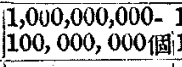 & $\begin{array}{l}100,000,000- \\
10,000,000 \text { 㮯 }\end{array}$ & $\begin{array}{l}0,000,000 \\
1,000,00\end{array}$ & \begin{tabular}{|r|}
$1,000,000$ \\
100,000 個
\end{tabular} & $\begin{array}{l}100,000- \\
\text { 個以下 }\end{array}$ \\
\hline 1例 & 7例 & 17例 & 17例 & 6例 & 0 \\
\hline 0 & 0 & 4 & 15 & 17 & 6 \\
\hline 0 & 5 & 8 & 20 & 19 & 4 \\
\hline
\end{tabular}


牛乳 1 c.c. 中に算出される細菌薮

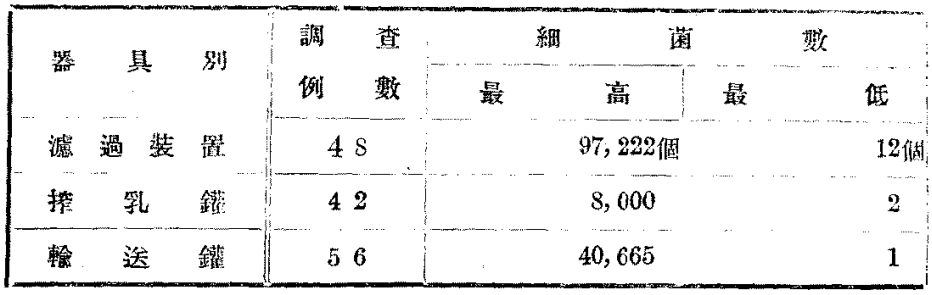

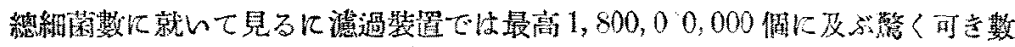

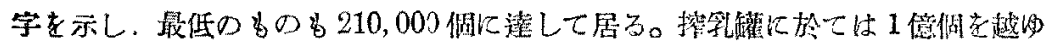

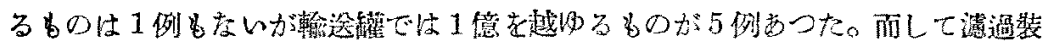

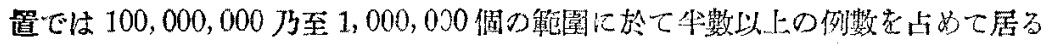

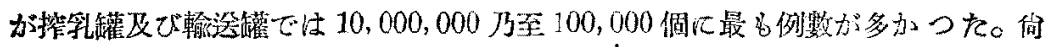

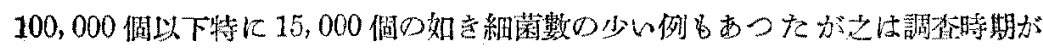

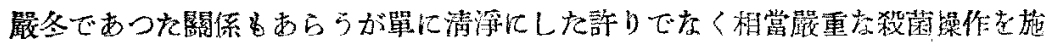

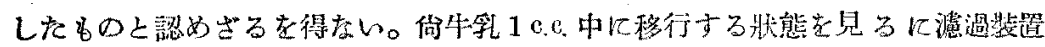

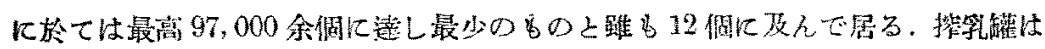

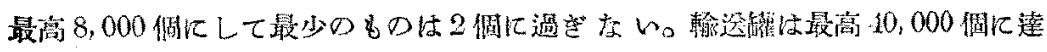

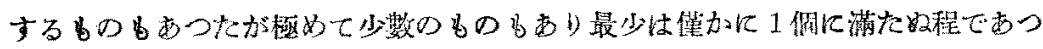

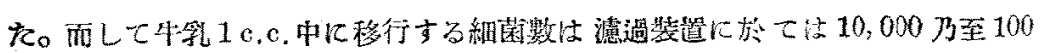

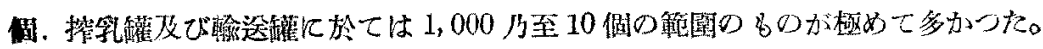

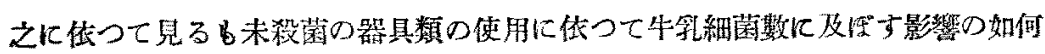
供大なるか在知り得るであらら。

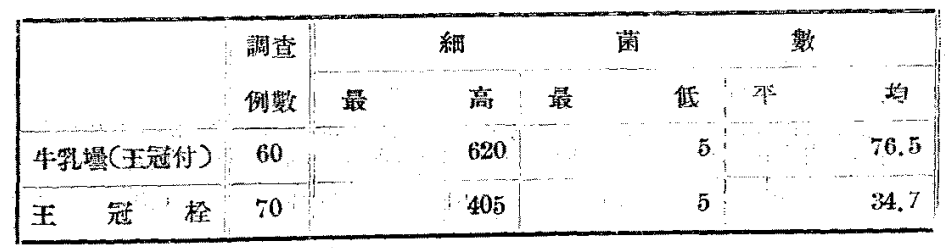

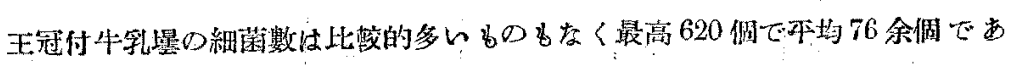

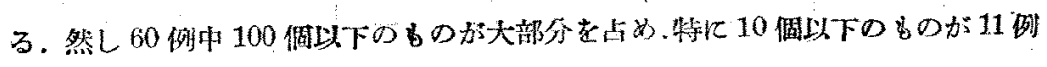




\begin{tabular}{|c|c|c|c|c|c|}
\hline & 例 & 数。 & 内 & 答 & \\
\hline 50,000 個以上 & $\begin{array}{l}50,000- \\
10,00 \text { 洒 }\end{array}$ & $\begin{array}{l}10,000= \\
1,0 \times \text { 㑬 }\end{array}$ & $\begin{array}{r}1,000 \\
100 \text { 㑑 }\end{array}$ & 100-10個 & 10佃以下 \\
\hline 1例 & 5例 & 15例 & 20 例 & 6例: & 1例 \\
\hline 0 & 0 & 4 & 17 & 15 & 6 \\
\hline 0 & 3 & 9 & 14 & 22 & 8 \\
\hline
\end{tabular}

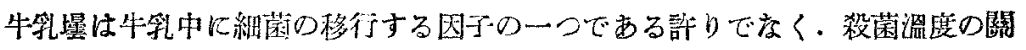

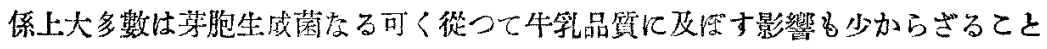

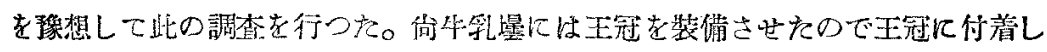

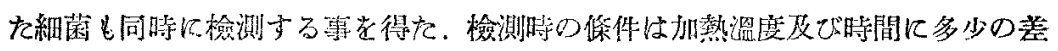

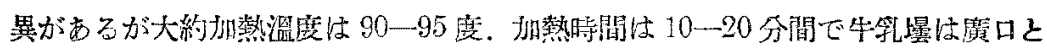

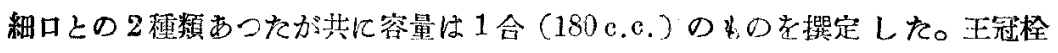

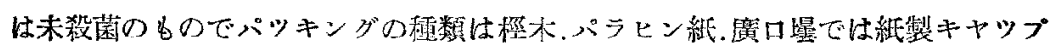

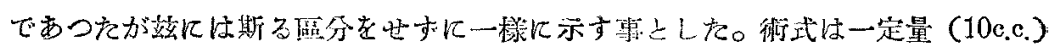

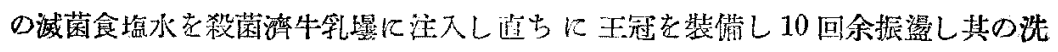
滌液に就を細菌數を检测した。

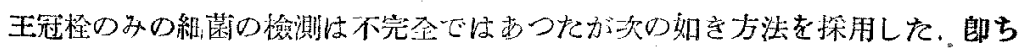

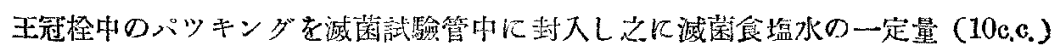

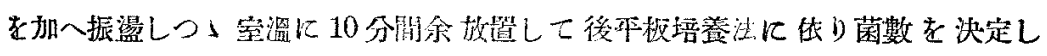

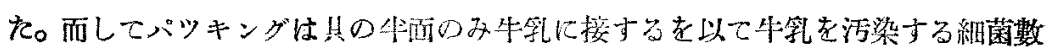
は次表の2分の 1 と見る可至でもる。

\begin{tabular}{|c|c|c|c|c|}
\hline 例 & 數 & 內 & 疽 & \\
\hline 50 遇以上 & $500-100$ 個 & $100-50$ 倜 & $50-10$ 個 & 10個以下 \\
\hline 4 & 7 & 12 & 24 & 11 \\
\hline 0 & 5 & 6 & 47 & 12 \\
\hline
\end{tabular}

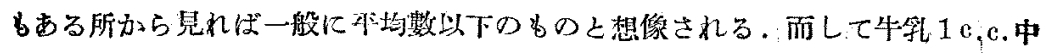
几移行する菌数は最高 3 個余りで大多数は 0.5 個以下でする。 


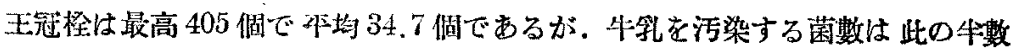
之見做す可をだから牛乳 1 e.c.中に移行する細菌數の最高は 1 合懪に於ては 1.1

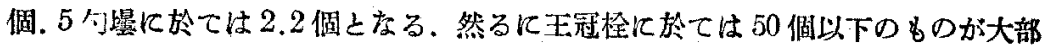
分を占めて居るから一般に牛乳に移行する細菌謷は極めて少いものと思はれる。

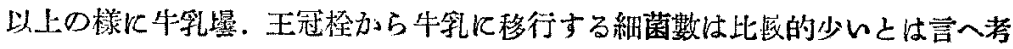
一㥞に依つては完全に秌菌せられて居ると信じられて居る 1 合の牛乳㟺より最高

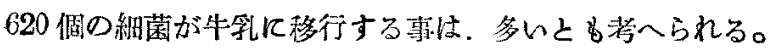

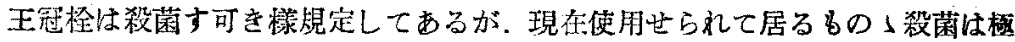

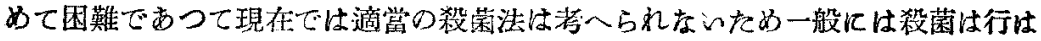

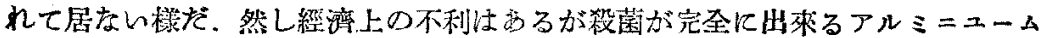

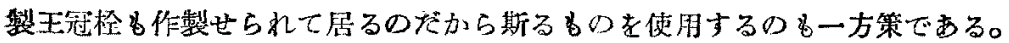

\section{V. 搾乳夫の手の細菌數}

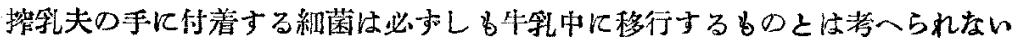
が、牛乳污染の一條化と就り得る事は言ふ迄るない事である。調查時の條件は。

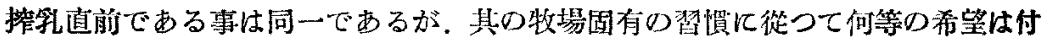
せをかつたので清拭つ程度等區そであつた。

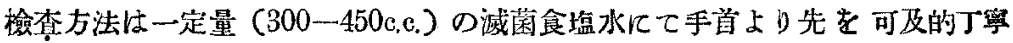

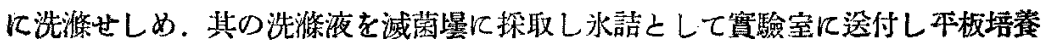
法に传つて菌數を汰定した。

調㜀例數は 20 例に過ぎないが，其の最高は $229,500,003$ 個に及び 1 億を越ゆ

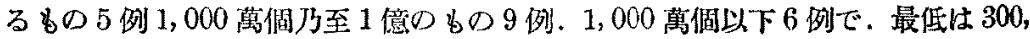
000 個であつた．右の如く手の細菌數は相當多數であるが之が牛乳に移行する彇 況は芼く不明である。從つて手を清潔にして如何程の效果があるか制然しないが 清絜にする事に依つて細菌の牛乳中に移行する一心機會を除く事が出來る事は確

\section{I. 熱湯 1 分間殺菌}

總菌数

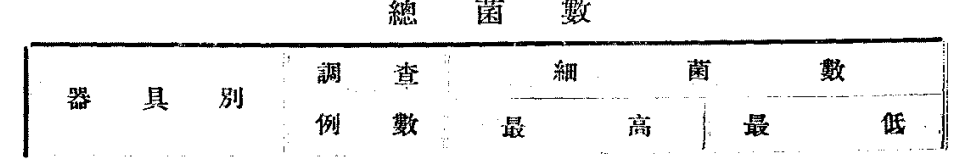


實である。

\section{VI. 搈孚器县の殺菌試驗}

峳䄻器具の殺菌に關しては省令に於て之を規定する所であるが. 經濟上其の他

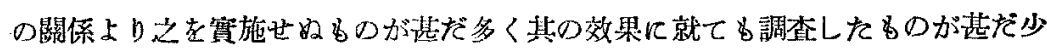
い煫でする，故に殺菌操作を施したるのに就調查して其の效果を明にする事は

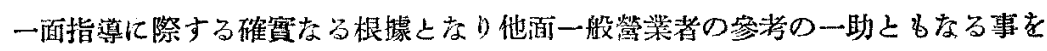
信じでを施行した。

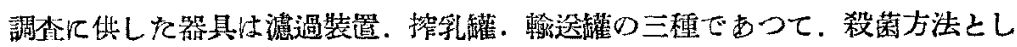

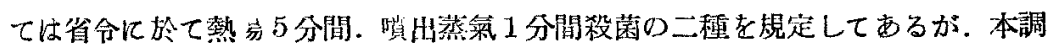
查に際しては以上の外熱湯 1 分間. バック殺菌。質出蒸氣 15 秒間殺菌をる併せ 行つたが其つ方法は次の如くである。

○熱湯殺菌法 釡文は蒸氣に依り沸騰せしめたる熱湯中に該器其を所要時間淁 漬して後放冷した。

○賁出蒸氣殺菌法 噴出蔡氣に依る刹菌は其の設備が處理所に限られて居るの

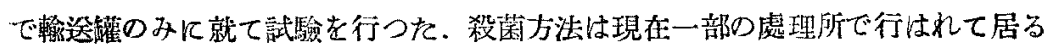

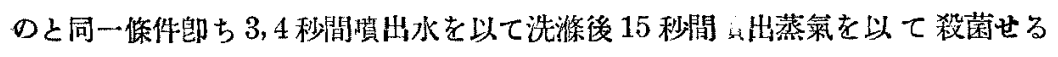

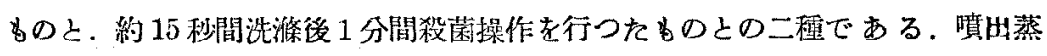
氣の蒸氣娾力壮的 15 ポンドであつて其の溫度は115 度內外であつた。

○バック殺菌法 バック殺菌を施行するに際してバック內の蒸氧厴力郎ち溫度 を知る事は重要な事ではするが。否儿ど計器の設備なく不明であつたが唯 1 ケ所

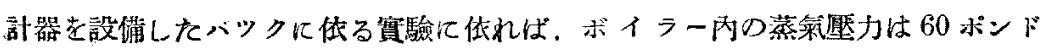

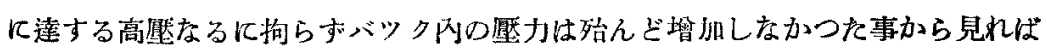

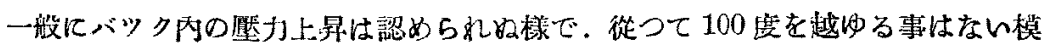
栏である。售殺菌時間は各牧場に依つて各々異るが大體 15 分乃至 30 分閒の範圍 內であつた。試騟方法は前述のものと同一である。

\begin{tabular}{|c|c|c|c|c|c|}
\hline . & 例 & 數 & 內 & 容 & \\
\hline $\begin{array}{l}500,000 \\
\text { 以上 }\end{array}$ & $\begin{array}{r}500,000- \\
1,0,000\end{array}$ & $\begin{array}{r}100,00)- \\
10,000\end{array}$ & $\begin{array}{r}10,000- \\
1,000\end{array}$ & $\begin{array}{r}1,000= \\
100\end{array}$ & 100 以下 \\
\hline
\end{tabular}




\begin{tabular}{|c|c|c|c|c|c|}
\hline 濾 & 過 裝 & 置 & 20 & $7,290,000$ 偪 & 300個 \\
\hline 橴 & 絮 & 䉜 & 28 & 169,000 & 150 \\
\hline 輞 & 送 & 政籍 & 25 & 56,400 & 300 \\
\hline & 한 & & 73 & $7,290,000$ & 150 \\
\hline
\end{tabular}

牛乳1e.c.中 $九$ 算出

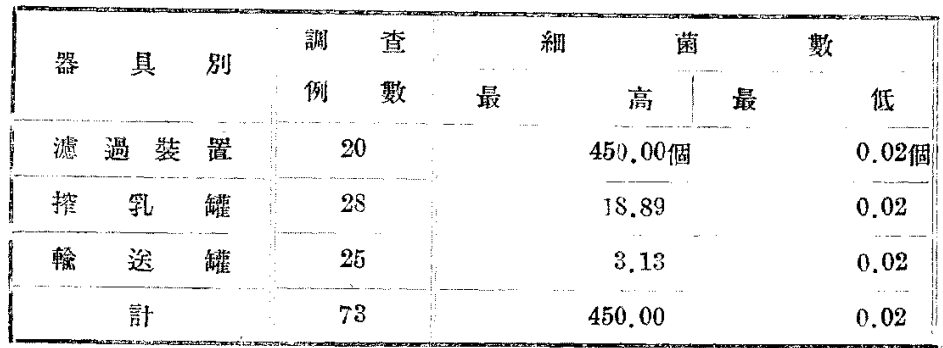

\section{2. 熱湯 5 分間殺菌}

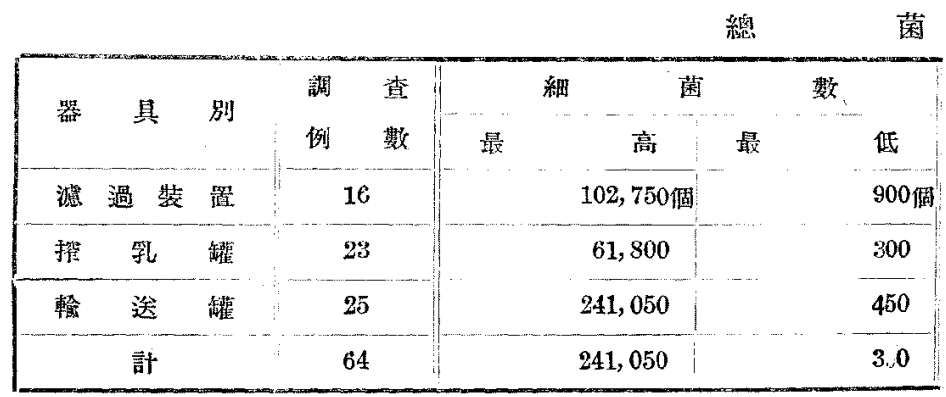

牛乳 1 c.c.中心 算州

\begin{tabular}{|c|c|c|c|c|c|c|c|}
\hline \multirow{2}{*}{ 器 } & \multirow{2}{*}{ 具 } & \multirow{2}{*}{ 别 } & 調 & & 細 & \multicolumn{2}{|c|}{ 數: } \\
\hline & & & 例 & 數 & 留 & 最 & 低 \\
\hline 潈 & 過 裝 & 瞋 & \multicolumn{2}{|c|}{16} & 5.70 拨 & & 0.05 個 \\
\hline 摧 & 彯 & 權 & \multicolumn{2}{|c|}{23} & 6.86 & & 0.03 \\
\hline \multirow[t]{2}{*}{ 瞺 } & 䢪 & 鑵 & & & & & 0.03 \\
\hline & 壾! & & & 4 & 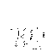 & & 0.03 \\
\hline
\end{tabular}




\begin{tabular}{r|r|r|r|r|r|}
\hline 1 例 & 0 例 & 4 例 & 12 例 & 3 例 & (例 \\
\hline 0 & 2 & 4 & 9 & 13 & 0 \\
\hline 0 & 0 & 6 & 14 & 5 & 0 \\
\hline 1 & 2 & 14 & 35 & 21 & 0 \\
\hline
\end{tabular}

される細 菌數

\begin{tabular}{|c|c|c|c|c|c|c|c|}
\hline & \multicolumn{2}{|c|}{ 例 } & 数 & 冈 & \multicolumn{2}{|l|}{ 容 } & \\
\hline 100 & 以上 & $100-10$ & $10-1$ & $1-0.1$ & $0.1-0.01$ & 0.01 以 & \\
\hline & 1例 & 例 & 1例 & 11例 & 7 例 & & 0例 \\
\hline & 0 & 2 & 5 & 8 & 13 & & 0 \\
\hline & 0 & 0 & 2 & 15 & 8 & & 0 \\
\hline & 1 & 2 & 8 & 34 & 28 & & 0 \\
\hline
\end{tabular}

数

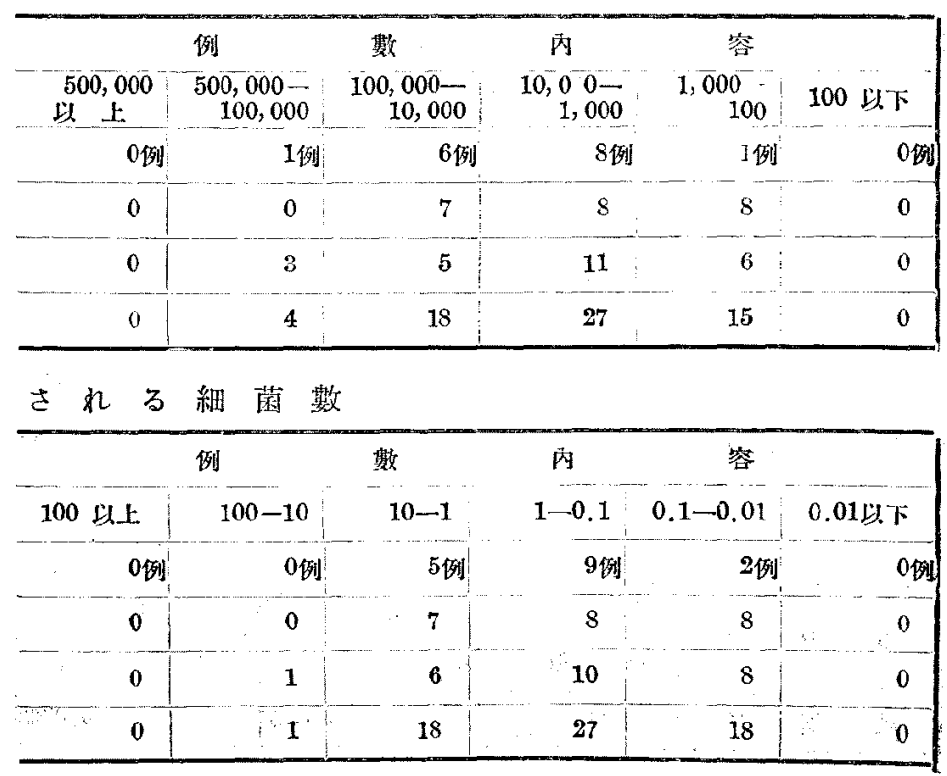




\section{3、バック殺菌}

總

药

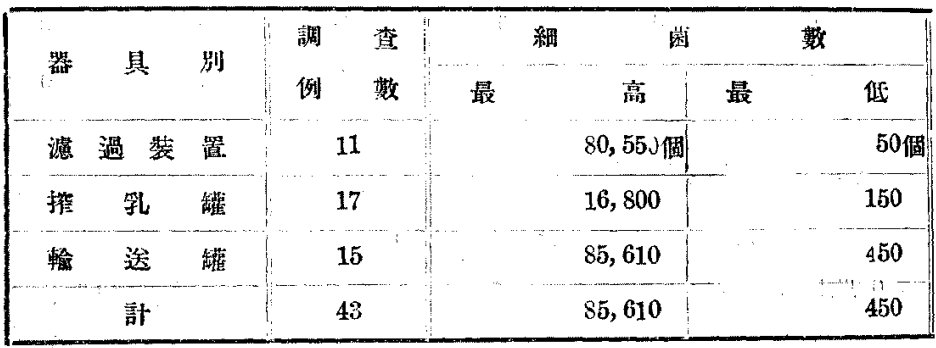

牛乳 1 c.c.K 算 出

\begin{tabular}{|c|c|c|c|c|c|c|c|c|}
\hline \multirow{2}{*}{ 器 } & \multirow{2}{*}{ 具 } & \multirow{2}{*}{ 别 } & & & \multicolumn{2}{|c|}{ 細 } & \multicolumn{2}{|c|}{ 數 } \\
\hline & & & 例 & 數 & 最 & 高 & 最 & 低 \\
\hline 憈 & 過 漿 & 路 & & & & 4.50倜 & & 0.003 偶 \\
\hline 挷 & 乳 & 罐 & & & & 1.87 & & 0.02 \\
\hline 輸 & 送 & 䙮 & & 5 & & 4.76 & & 0.03 \\
\hline & 計 & & & 3 & & 4.76 & & 0.003 \\
\hline
\end{tabular}

\section{4. 喷出蒸氣 15 秒殺菌}

\begin{tabular}{|c|c|c|c|c|c|c|c|c|}
\hline \multirow{2}{*}{ 器 } & \multirow{2}{*}{ 具 } & \multirow{2}{*}{ 别 } & & & & 菌 & 數 & \\
\hline & & & 例 & 数 & 最 & 高 & 最 & 低 \\
\hline 輸 & 䢪 & 罐 & & & & 138,000 個 & & 450 個 \\
\hline
\end{tabular}

牛 乳1c.c.中 $下$ 算

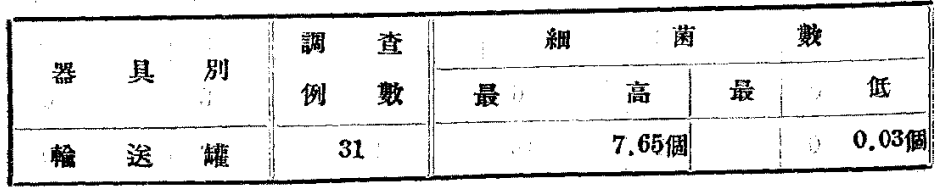


隺

\begin{tabular}{|c|c|c|c|c|c|c|}
\hline & 例 & ; & \multicolumn{4}{|c|}{ 數 } \\
\hline 500,000 以上 & $\begin{array}{r}500,000- \\
100,000\end{array}$ & $\begin{array}{r}100,000 \\
10,000\end{array}$ & $\begin{array}{r}10,000 \rightarrow \\
1,000\end{array}$ & $1,000-100$ & 100 以 & \\
\hline O例 & o列 & 3例 & 4 例 & 3例 & & 1例 \\
\hline 0 & 0 & 1. & 8 & 8 & & 0 \\
\hline 0 & 0 & 2 & 7 & 6 & & 0 \\
\hline 0 & 0 & 6 & 19 & 17 & & 1 \\
\hline
\end{tabular}

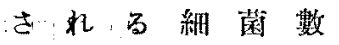

\begin{tabular}{|c|r|r|r|r|r|}
\hline 100 以上 & $100-10$ & $10-1.0$ & $1-0,1$ & $0.1-0.01$ & $0.01 以 下$ \\
\hline 0 例 & 0 例 & 2 例 & 4 & 4 & 1 例 \\
\hline 0 & 0 & 1 & 11 & 6 & 0 \\
\hline 0 & 0 & 1 & 5 & 9 & 0 \\
0 & 0 & 4 & 19 & 19 & 1 \\
\hline
\end{tabular}

霉

\begin{tabular}{|c|c|c|c|c|c|}
\hline \multicolumn{2}{|r|}{ 例 } & 数 & 内 & 签 & \\
\hline 500,000 以上 & $\begin{array}{r}500,000- \\
100,000\end{array}$ & $\begin{array}{r}100,00^{0} \\
1,000\end{array}$ & $\begin{array}{r}10,000= \\
1,000\end{array}$ & $\begin{array}{r}1,000= \\
100\end{array}$ & 100 以下 \\
\hline 0 & 1. & 18 & 10 & 2 & 0 \\
\hline
\end{tabular}

される緗菌數

\begin{tabular}{r|r|r|r|r|r|}
\hline & \multicolumn{3}{|c|}{ 例 } & 數 & \multicolumn{3}{|c|}{ 内 } \\
\hline 100 以上 & $100-10$ & $10-1$ & $1-0.1$ & $0.1-0.01$ & 0.01 以下 \\
\hline 0 例 & 0 例 & 16 例 & 5 例 & 10 例 & 0 湖 \\
\hline
\end{tabular}




\section{5. 噴出蒸㴋 1 分間殺菌}

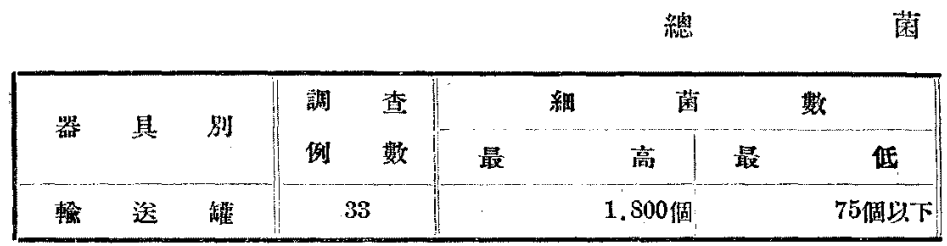

牛乳1c.c.中下算出

\begin{tabular}{|c|c|c|c|c|c|c|c|c|c|}
\hline \multirow{2}{*}{ 器 } & \multirow{2}{*}{ 具 } & \multirow{2}{*}{ 别 } & 調 & & \multirow{3}{*}{ 最 } & \multirow[t]{2}{*}{ 細 } & \multicolumn{2}{|c|}{ 菌 } & 數 \\
\hline & & & 例 & 数 & & & 高 & 最 & 低 \\
\hline 鐱 & 遑 & 蠸 & & & & & 0.10 個 & & 0.004個以下 \\
\hline
\end{tabular}

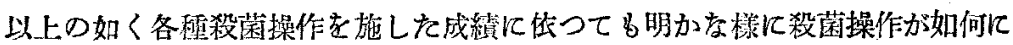

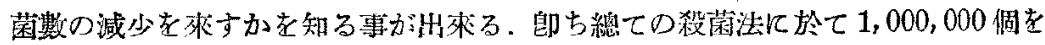

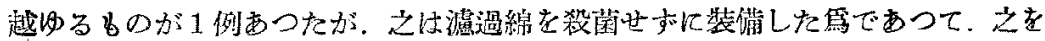

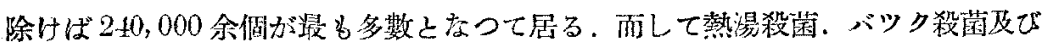

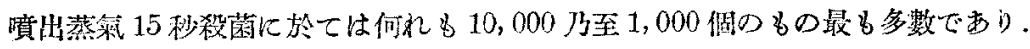

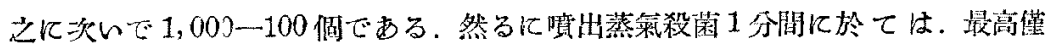

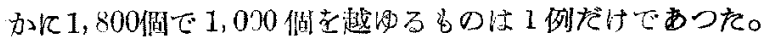

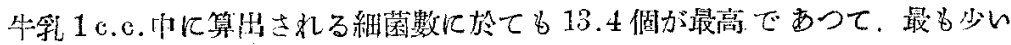

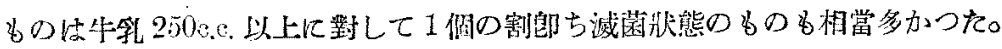

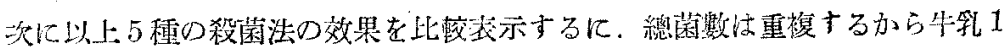

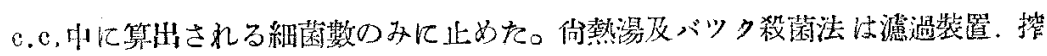

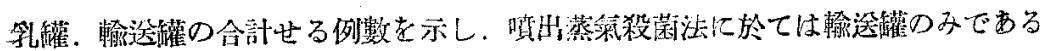

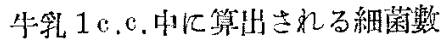

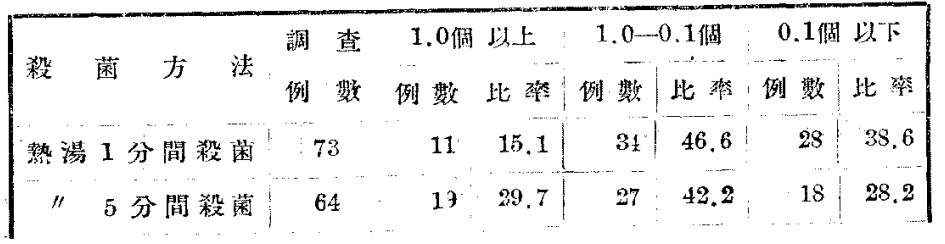


数

\begin{tabular}{|c|c|c|c|c|c|}
\hline & 例 & 數 & 內 & 答 & \\
\hline 500,000 以上 & $\begin{array}{r}500,000- \\
100,000\end{array}$ & $\begin{array}{r}100,000- \\
10,000\end{array}$ & $\begin{array}{r}10,000- \\
1,000\end{array}$ & $1,000-100$ & 100 以下 \\
\hline 0 例 & 0例: & 0 例 & 2例 & 17例 & 14例 \\
\hline
\end{tabular}

される 絧 菌 數

\begin{tabular}{|c|c|c|c|c|c|}
\hline & 例 & 僦 & 内 & 容 & \\
\hline 100 以上 & $100-10$ & $10-1$ & $x-0.1$ & $0.1-0.01$ & 0.01 以下 \\
\hline O例: & 0例 & 0 例 & 1例 & 11例 & 21 例 \\
\hline
\end{tabular}

\begin{tabular}{|c|c|c|c|c|c|c|c|}
\hline バック殺 菌 & 43 & 4 & 9.3 & 19 & 44.2 & 20 & 46.5 \\
\hline 噴出蒸集15移間殺菌 & 31 & 16 & 51.6 & 5 & 16.1 & 10 & 32.3 \\
\hline " 1 分間殺菌 & 33 & 0 & 0 & 1 & 3.0 & 32 & 97.0 \\
\hline
\end{tabular}

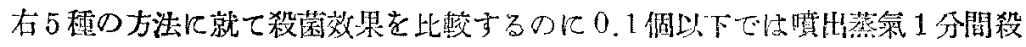

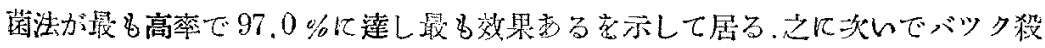

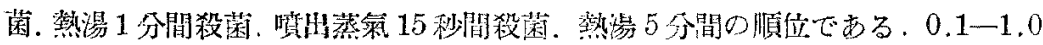

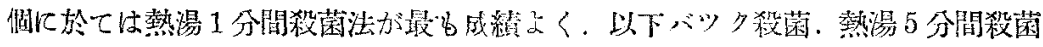

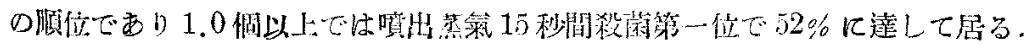

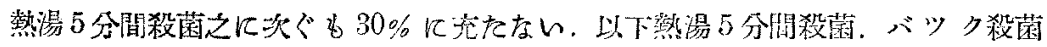
○順位上故つて居る。

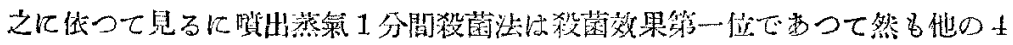

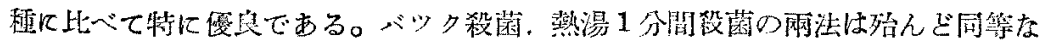

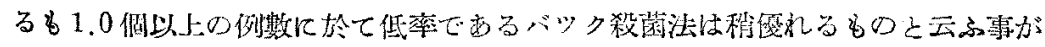

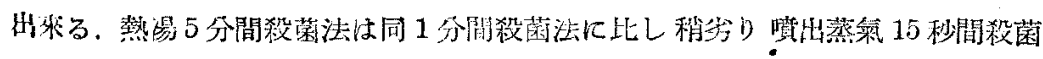

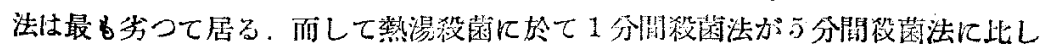

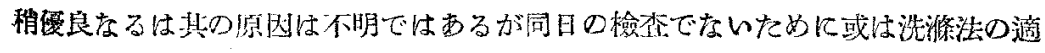




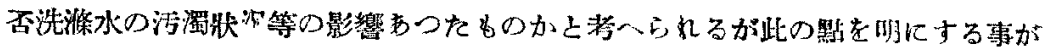
出來なかつたのは遗㗪であつた。

\section{VII，總 括}

（1）乳頚管腔より牛乳中に細菌の移行する狀態は第一些。第三㵠にあつては 米だ相當多數であるが．第五搾りに至つては殆んど $1 \mathrm{c}, \mathrm{c}$. 中 1,000 倜以下に減少

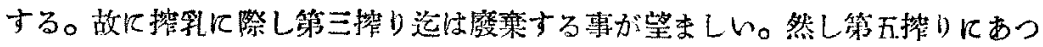

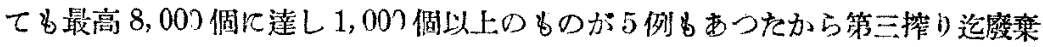

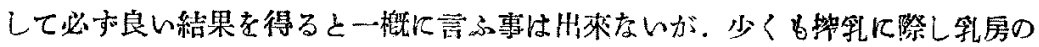

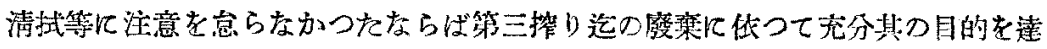
し得る事々磪信する。

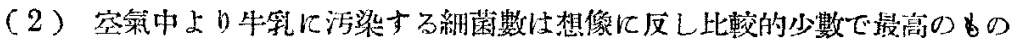

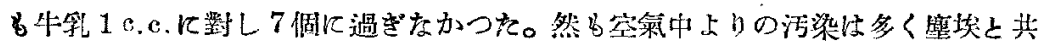

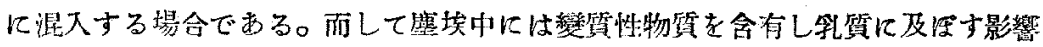

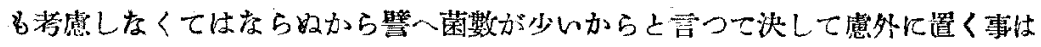

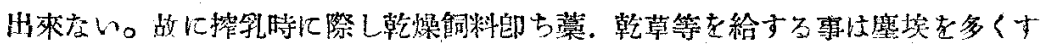

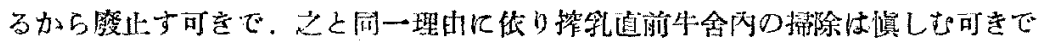
ある。

(3) 乳器具よりの活染狀態は菌數少を10月より釷年3月の間であつたに

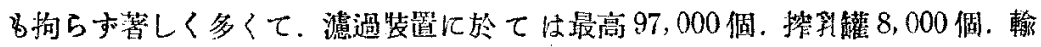

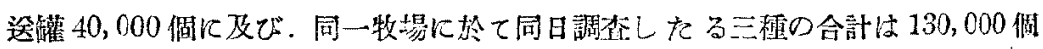
に達したものがあつた。而して比較的細菌繁殖の弱い時期に於てさ八斯くの如く

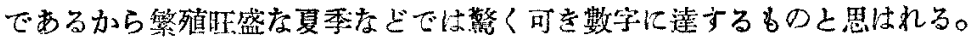

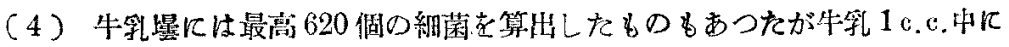
算出される菌數は大多數に然て 1 偑に古たなかつた. 而してバツク殺菌を施行し

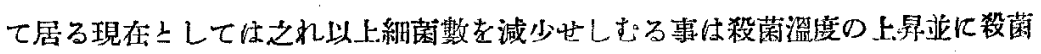
時間を延長しなりればなら如ので實際上に於ては余程因奞索事上将入られる。

(5) 王冠柽には最高 450 㑑に及ぶのもあつたが多くは100個に立たなか

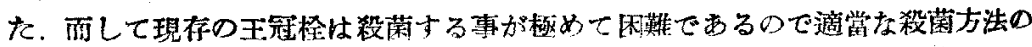




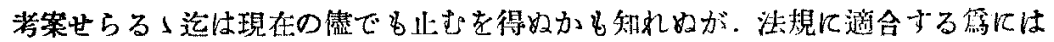

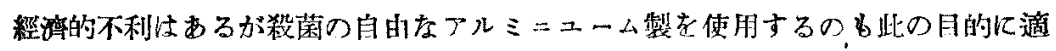
ふくのと認める。

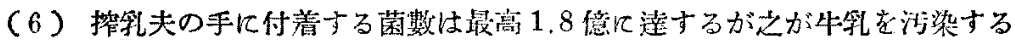

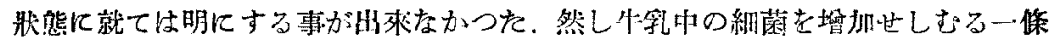

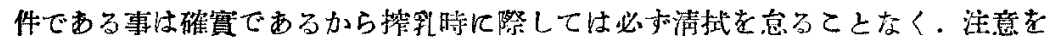
㘫ふ可をである。

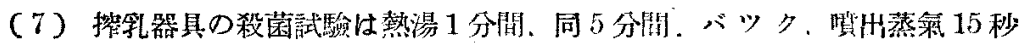

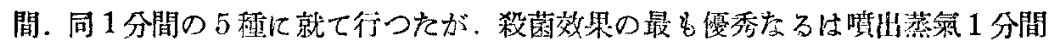

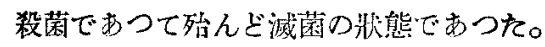

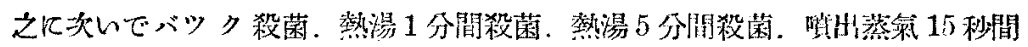

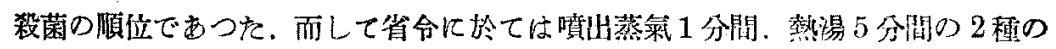

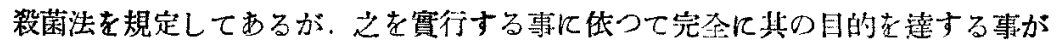

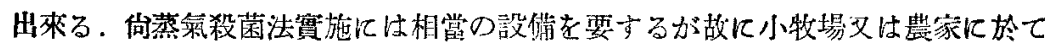
は嘪行不可能であるが熱湯に依る殺菌法は何等の設備を要せす僅かの手數により 簡單に實行する事が出來るからをを造けてはならない。

（8）以上の成績に依つて明かな如く細菌數の少い特乳生霅するためには結

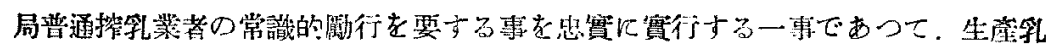

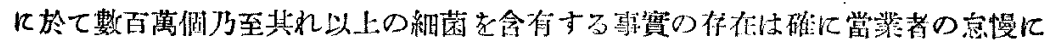
歸して美支ないと考つられるのである。 